\title{
Slow Unfolding Pathway of the Hyperthermophilic Tk-RNase H2 Examined by Pulse Proteolysis Using Mutant Proteins
}

Kanako Shima, Ai Nagao, Jun Okada, Satoshi Sano and Kazufumi Takano*

Department of Biomolecular Chemistry, Kyoto Prefectural University, Kyoto, Japan

\begin{abstract}
The unfolding of ribonuclease $\mathrm{H} 2$ from the hyperthermophilic archaeon Thermococcus kodakarensis (Tk-RNase $\mathrm{H} 2$ ) is remarkably slow. In previous work, Tk-RNase $\mathrm{H} 2$ unfolding intermediates, $\mathrm{I}_{\mathrm{A}^{-}}, \mathrm{I}_{\mathrm{B}} \mathrm{B}^{-}, \mathrm{I}_{\mathrm{C}^{-}}$and $\mathrm{I}_{\mathrm{D}}$-states, were observed by pulse proteolysis analysis at $25^{\circ} \mathrm{C}$, where the $\mathrm{I}_{\mathrm{B}}$ - and $\mathrm{I}_{\mathrm{C}}$-states are the main forms in the slow unfolding process of this protein. Here, we examined the slow unfolding pathway of Tk-RNase $\mathrm{H} 2$ by pulse proteolysis using mutants. For the stabilized variant, D7N, the life time of $\mathrm{I}_{A}$ - and $\mathrm{I}_{B}$-states decreased but the $\mathrm{I}_{C}$-state appeared earlier at $25^{\circ} \mathrm{C}$, indicating the stabilization of the $\mathrm{I}_{C}$-state. The $\mathrm{I}_{\mathrm{A}}$ - and $\mathrm{I}_{\mathrm{B}}$-states were not observed in the destabilized variant, $\mathrm{L} 33 \mathrm{~A}$, at $25^{\circ} \mathrm{C}$, whereas in the wild-type these two states disappeared at $50^{\circ} \mathrm{C}$. Our results suggest that at higher temperatures the $\mathrm{I}_{C}$-state is the real native state of Tk-RNase $\mathrm{H} 2$, whereas the native, $\mathrm{I}_{\mathrm{A}}$ - and $\mathrm{I}_{\mathrm{B}}$-states at $25^{\circ} \mathrm{C}$ are artificial forms at lower temperatures.
\end{abstract}

Keywords: Ribonuclease H2; Thermococcus kodakarensis; Unfolding intermediate; Subtilisin

\section{Introduction}

Ribonuclease $\mathrm{H} 2$ from the hyperthermophile, Thermococcus kodakarensis (Tk-RNase $\mathrm{H} 2$ ), is a monomer, consists of 228 residues and has a molecular weight of $26 \mathrm{kDa}$ [1]. RNase $\mathrm{H}$ hydrolyzes only the RNA strand of an RNA/DNA hybrid [2]. The enzyme is ubiquitously present in various organisms and is involved in DNA replication and repair. $\mathrm{RNase} \mathrm{H}$ is classified into two major types according to sequence similarity, Type 1 and Type 2 RNase H [3]. Tk-RNase H2 is a Type 2 RNase $\mathrm{H}$. The crystal structures of Tk-RNase $\mathrm{H} 2$ and several variants have been determined [4-6]. The stability and folding/unfolding experiments of Tk-RNase $\mathrm{H} 2$ are well documented [7-14]. Tk-RNase $\mathrm{H} 2$ is highly stable, and its stabilization mechanism is characterized by its remarkably slow unfolding. Hydrophobic and proline mutants of Tk-RNase $\mathrm{H} 2$ showed that hydrophobic effects were responsible for the slow unfolding and not proline residues.

In a previous study, we monitored the intermediate structures of Tk-RNase $\mathrm{H} 2$ in the slow unfolding pathway using pulse proteolysis and a super-stable protease in the presence of the denaturant guanidine hydrochloride (GdnHCl) [14]. Subtilisin from the hyperthermophilic archaeon T. kodakarensis (Tk-subtilisin) is a protease that displays high stability and activity at high temperatures, and is stable in the presence of chemical denaturants [15-25]. We successfully determined regions that constitute the kinetic unfolding intermediates and observed the unfolding behavior of Tk-RNase H2. Tk-RNase H2 includes multiple intermediate forms, $I_{A^{-}}, I_{B}-, I_{C}-$ and $I_{D}$-states, during the unfolding process [14]. The unfolding reaction of the $I_{B}{ }^{-}$and $I_{C}$-states is ratelimiting in the slow unfolding process of Tk-RNase $\mathrm{H} 2$. The results also showed that slow unfolding is attributed to the $\mathrm{N}$-terminal region and conformational changes to the $\mathrm{C}$-terminal region occur during unfolding or with an increase in temperature.

In this report, to characterize the unfolding process of Tk-RNase $\mathrm{H} 2$ in more detail, we have examined the slow unfolding pathway of Tk-RNase $\mathrm{H} 2$ by pulse proteolysis using selected mutants. The mutant D7N is a stabilized variant of the wild-type protein [8], whereas L33A is a destabilized variant [9]. Both mutation sites are located in the $\mathrm{N}$-terminal domain. The pulse proteolysis results of the two mutants differed to that of the wild-type protein. We also confirmed the results using D7N-F20 and L33A-F20, which are derived from residues 1-176 Tk-RNase H2 (F20) [14]. F20 corresponds to the $\mathrm{I}_{B}$-state in the unfolding pathway of Tk-RNase H2. F20 is a digested form in the C-terminal region. Based on the results obtained, we discuss the slow unfolding pathway of Tk-RNase $\mathrm{H} 2$.

\section{Methods}

\section{Plasmids, overproduction and purification of target proteins}

Plasmids for the overexpression of Tk-RNase H2, F20, D7N and L33A were constructed as described previously $[1,8,9,14]$. Plasmids for the overexpression of the mutant D7N-F20 and L33A-F20 were constructed from F20 using standard recombinant DNA techniques. Tk-RNase $\mathrm{H} 2$ and its variants were overproduced and purified as described previously $[1,8,9,14]$. Protein purity was analyzed by SDSPAGE using a $15 \%$ polyacrylamide gel and stained using Coomassie Brilliant Blue staining.

\section{Kinetic experiments on GdnHCl-induced unfolding}

Unfolding reactions were followed by CD measurements at 220 $\mathrm{nm}$, as described previously [14]. The optical path length was $1 \mathrm{~cm}$. The kinetic data were analyzed using:

$$
\mathrm{A}(\mathrm{t})-\mathrm{A}(\infty)=\Sigma \mathrm{A}_{\mathrm{i}} \mathrm{e}^{-\mathrm{kit}}
$$

where $A(\mathrm{t})$ is the value of the $\mathrm{CD}$ signal at a given time $t, A(\infty)$ is the value when no further change is observed, $k \mathrm{i}$ is the apparent rate constant of the $i$ th kinetic phase and $A \mathrm{i}$ is the amplitude of the $i$ th phase. The fitting used SigmaPlot (SYSTAT, IL). All kinetic experiments were

*Corresponding author: Kazufumi Takano, Department of Biomolecular Chemistry, Kyoto Prefectural University, Kyoto, Japan, Tel: +81-75-703-5654; Fax: +81-75-703-5654; E-mail: takano@kpu.ac.jp

Received: August 30, 2015; Accepted: October 19, 2015; Published October 22, 2015

Citation: Shima K, Nagao A, Okada J, Sano S, Takano K (2015) Slow Unfolding Pathway of the Hyperthermophilic Tk-RNase H2 Examined by Pulse Proteolysis Using Mutant Proteins. Biochem Anal Biochem 4: 213. doi:10.4172/21611009.1000213

Copyright: @ 2015 Shima K, et al. This is an open-access article distributed under the terms of the Creative Commons Attribution License, which permits unrestricted use, distribution, and reproduction in any medium, provided the original author and source are credited. 
performed in $20 \mathrm{mM}$ Tris- $\mathrm{HCl}, \mathrm{pH} 9.0$. The protein concentration was $0.032-0.16 \mathrm{mg} \mathrm{ml}^{-1}$.

\section{Pulse proteolysis in kinetic unfolding by Tk-subtilisin}

The protein was unfolded in $20 \mathrm{mM}$ Tris- $\mathrm{HCl}$ ( $\mathrm{pH}$ 9.0) containing 4 $\mathrm{M} \mathrm{GdnHCl}$ at 25 or $50^{\circ} \mathrm{C}$. Reactions were dispensed into aliquots $(50 \mu \mathrm{l})$. At designated time points, $2 \mu \mathrm{l} \mathrm{Tk}$-subtilisin at several concentrations in $10 \mathrm{mM}$ acetate buffer ( $\mathrm{pH} 5.0)$ was added to each aliquot. After $45 \mathrm{~s}$, the reaction was quenched by $10 \%(\mathrm{w} / \mathrm{v})$ TCA. Proteins were precipitated using $10 \%(\mathrm{w} / \mathrm{v})$ TCA, washed with $70 \%$ acetone and analyzed by $15 \%$ tricine-SDS-PAGE [14]. The concentrations of TkRNase H2, the variants and Tk-subtilisin were optimized at each experiment depending on the stability and unfolding rate of Tk-RNase $\mathrm{H} 2$ and its variants. The amount of protein was estimated from the intensity of the band visualized with Coomassie Brilliant Blue staining using image $J[26]$.

\section{Results and Discussion}

\section{Stability of Tk-RNase $\mathrm{H} 2$ and its variants}

The thermal unfolding properties of Tk-RNase H2, D7N, L33A and F20 have been examined previously $[8,9,14]$. The changes in the $T_{\mathrm{m}}$ value $\left(\Delta T_{\mathrm{m}}\right)$ of the variants compared with the wild-type Tk-RNase $\mathrm{H} 2$ are summarized in Table $1 . \mathrm{D} 7 \mathrm{~N}$ is stabilized, whereas $\mathrm{L} 33 \mathrm{~A}$ is destabilized. The $T_{\mathrm{m}}$ value of F20 is slightly higher than the $T_{\mathrm{m}}$ value of the wild-type protein.

\section{Unfolding of Tk-RNase $\mathrm{H} 2$ and its variants examined by $\mathrm{CD}$ spectroscopy}

The kinetics of GdnHCl-induced unfolding of Tk-RNase $\mathrm{H} 2$ and its variants were examined at 25 or $50^{\circ} \mathrm{C}$. The reaction was initiated by a jump to 3.2 or $4 \mathrm{M} \mathrm{GdnHCl} \mathrm{followed} \mathrm{by} \mathrm{far-UV} \mathrm{CD} \mathrm{signal} \mathrm{recording}$ at $220 \mathrm{~nm}$. The kinetic unfolding curves are shown in Figure 1. RNase $\mathrm{H} 2$ and the D7N mutant unfolding at $25^{\circ} \mathrm{C}$ (Figure 1A and $1 \mathrm{~B}$ ) was characterized by signal changes in the far-UV CD within dead times $(\sim 2 \mathrm{~s})$. This indicates a burst phase in the kinetics of the slow unfolding of Tk-RNase $\mathrm{H} 2$ and D7N. The burst phase, which was $\sim 30 \%$ of the total signal changes between the unfolded and native states, was followed by a slower observable phase. The slow unfolding phase after the burst phase was approximated as a first-order reaction. In the other experiments at $25^{\circ} \mathrm{C}$ (Figure $1 \mathrm{C}$ and Figure $1 \mathrm{E}-1 \mathrm{G}$ ), the burst phase signal was not detected in the kinetic curves. The burst phase of TkRNase $\mathrm{H} 2$ at $50^{\circ} \mathrm{C}$ was about $20 \%$ of the total signal changes between the unfolded and native states, indicating a decrease in the burst phase with an increase in temperature (Figure 1D) [14]. The kinetic trace was approximated to a first-order reaction. The unfolding rate constants are listed in Table 2.

The unfolding rates of $\mathrm{D} 7 \mathrm{~N}$ and $\mathrm{L} 33 \mathrm{~A}$ are slower and faster,

\begin{tabular}{|c|c|}
\hline & $\Delta T_{\mathrm{m}}\left({ }^{\circ} \mathrm{C}\right)$ \\
\hline Tk-RNase H2 (wild-type) & $(85.7)^{\mathrm{a}}$ \\
\hline D7N & $3.1^{\mathrm{b}}$ \\
\hline L33A & $-11.9^{\mathrm{c}}$ \\
\hline F20 & $1.1^{\mathrm{d}}$ \\
\hline
\end{tabular}

${ }^{a} T_{m}$ value. Data from ref. [14].

'Data from ref. [8].

'Data from ref. [9].

${ }^{\mathrm{d} D a t a}$ from ref. [14].

Table 1: Change in the $T_{\mathrm{m}}$ value $\left(\Delta T_{\mathrm{m}}\right)$ of the variants compared with Tk-RNase $\mathrm{H} 2$ at $\mathrm{pH} 9.0$. respectively, than the unfolding rate of the wild-type protein, and clearly dependent on their stability. This pattern was also observed for F20 and its variants. The unfolding rate constant of F20 was equal to Tk-RNase $\mathrm{H} 2$ at 25 and $50^{\circ} \mathrm{C}$. The results indicate that $\mathrm{F} 20$ is a ratelimiting factor in the slow unfolding process of Tk-RNase $\mathrm{H} 2$.

\section{Unfolding of Tk-RNase $\mathrm{H} 2$ and its variants examined by pulse proteolysis}

Pulse proteolysis experiments were performed after the protein was unfolded in $20 \mathrm{mM}$ Tris- $\mathrm{HCl}$ (pH 9.0) containing $4 \mathrm{M} \mathrm{GdnHCl}$. The remaining intact protein and its degradation products were detected by tricine-SDS-PAGE (sodium dodecyl sulfate polyacrylamide gel electrophoresis), as shown in Figure 2.

In Figure 2A, an intact band and several cleavage products of TkRNase H2 were observed [14]. The intact band decreased in intensity to less than half the initial value in $0.5 \mathrm{~min}$. The amount of the intact protein at 0.5 and $1 \mathrm{~min}$ was less than that at 2 to $16 \mathrm{~min}$. These results indicate that a proportion of intact protein was digested ( $\mathrm{I}_{\mathrm{A}}$-state) in the early stages of unfolding. Two heavy chain fragments (fragments 22 and 20 ) at $\sim 20 \mathrm{kDa}$ appeared. The fragments correspond to the $\mathrm{I}_{\mathrm{B}}$-state. After $2 \mathrm{~min}$, the amount of intact protein increased, which represents the $I_{C}$-state. The bands of fragments 20 and 22 decreased in intensity at 30 to $60 \mathrm{~min}$, but the intensity of the band representing the intact protein was unaffected. That is, the $\mathrm{I}_{\mathrm{A}}$-state changes to forms $\left(\mathrm{I}_{\mathrm{B}}-\right.$ and $\mathrm{I}_{\mathrm{C}}$-states) that are partially and fully, respectively, resistant to Tk-subtilisin, and the $\mathrm{I}_{\mathrm{B}}$-state moves to the $\mathrm{I}_{\mathrm{C}}$-state during unfolding in GdnHCl. The Tk-subtilisin resistant form ( $\mathrm{I}_{\mathrm{C}}$-state) of Tk-RNase $\mathrm{H} 2$ gradually unfolded via the $\mathrm{I}_{\mathrm{D}}$-state and was subsequently degraded by Tk-subtilisin.

The result of pulse proteolysis at $25^{\circ} \mathrm{C}$ of $\mathrm{D} 7 \mathrm{~N}$ unfolding (Figure $2 \mathrm{~B}$ ) was similar to the wild-type unfolding result (Figure 2A). However, the $\mathrm{I}_{\mathrm{A}}$ - and $\mathrm{I}_{\mathrm{B}}$-states decreased and the $\mathrm{I}_{\mathrm{C}}$-state appeared earlier, indicating the stabilization of the $\mathrm{I}_{\mathrm{C}}$-state by the $\mathrm{D} 7 \mathrm{~N}$ mutation. For L33A, Figure $2 \mathrm{C}$ shows that the intact band decreased over time, but few degradation products were detected. This indicates the disappearance of the $\mathrm{I}_{\mathrm{A}}$ - and $\mathrm{I}_{\mathrm{B}}$-states in L33A unfolding. A similar result was also observed in the wild-type unfolding at $50^{\circ} \mathrm{C}$ (Figure 2D). L33A was degraded faster than the wild-type protein at $50^{\circ} \mathrm{C}$, depending on their unfolding rates (Table 2). These results suggest that the unfolding of the destabilized variant, $\mathrm{L} 33 \mathrm{~A}$, at $25^{\circ} \mathrm{C}$ and the wild-type protein at $50^{\circ} \mathrm{C}$ starts from the $\mathrm{I}_{\mathrm{C}}$-state. This is related to the disappearance and decrease of the burst phase signal during the kinetic unfolding of $\mathrm{L} 33 \mathrm{~A}$ at $25^{\circ} \mathrm{C}$ and the wildtype protein at $50^{\circ} \mathrm{C}$, respectively (Figure $1 \mathrm{C}$ and $1 \mathrm{D}$ ).

F20 loses the C-terminal region of Tk-RNase H2. The proteolysis experiments of $\mathrm{F} 20$ at $25^{\circ} \mathrm{C}$ indicated that the band intensities of the intact protein gradually disappeared over time and other bands did not appear (Figure 2E). The result is similar to that observed for D7N-F20 and L33A-F20 (Figure 2F and Figure 2G), whereas the degradation rate of D7N-F20 and L33A-F20 was slower and faster, respectively, than that seen for F20, and is dependent on the unfolding rate of the protein (Table 2). The results suggest that the mutations affect the stability of the $\mathrm{I}_{\mathrm{B}}$-state.

\section{Energy diagram of the unfolding pathway of Tk-RNAse $\mathrm{H} 2$}

Figure $3 \mathrm{~A}$ shows the schematic illustration for the energy diagram of the unfolding pathway of Tk-RNase $\mathrm{H} 2$ at $25^{\circ} \mathrm{C}$ and is based on previous work [14]. The $\mathrm{N}$ state changes to the $\mathrm{I}_{\mathrm{B}}$ - and $\mathrm{I}_{\mathrm{C}}$-states, which are stable intermediate forms, through the $\mathrm{I}_{\mathrm{A}}$-state. The intermediate forms unfold via the $\mathrm{I}_{\mathrm{D}}$-state. In D7A and L33A, the mutations stabilize 
(A)

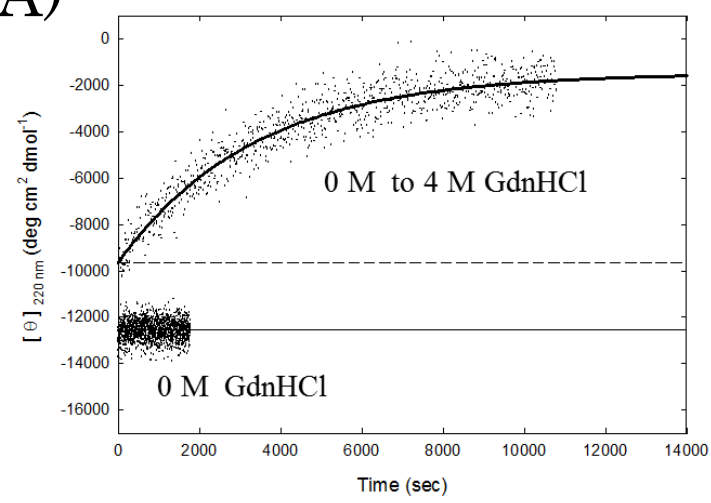

(B)

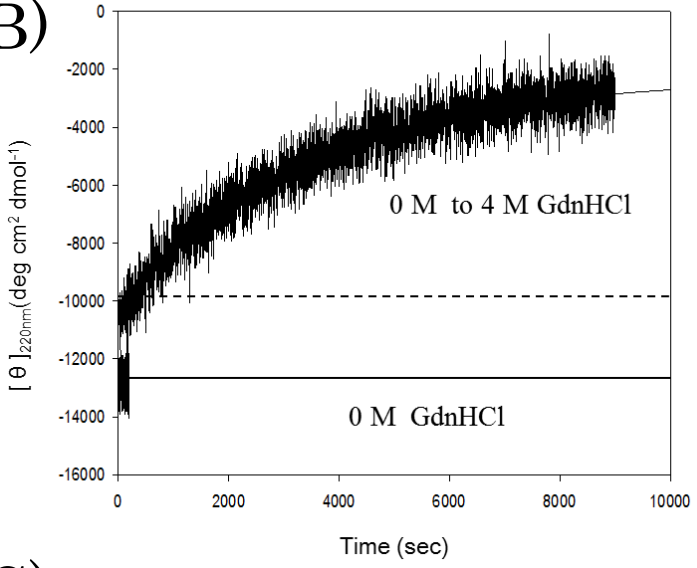

(C)

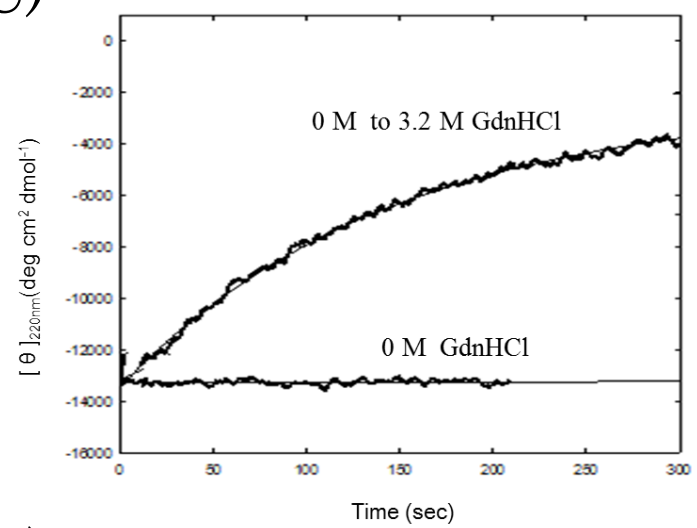

(D)

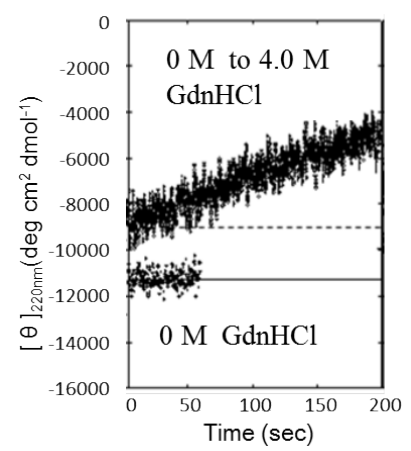

(E)

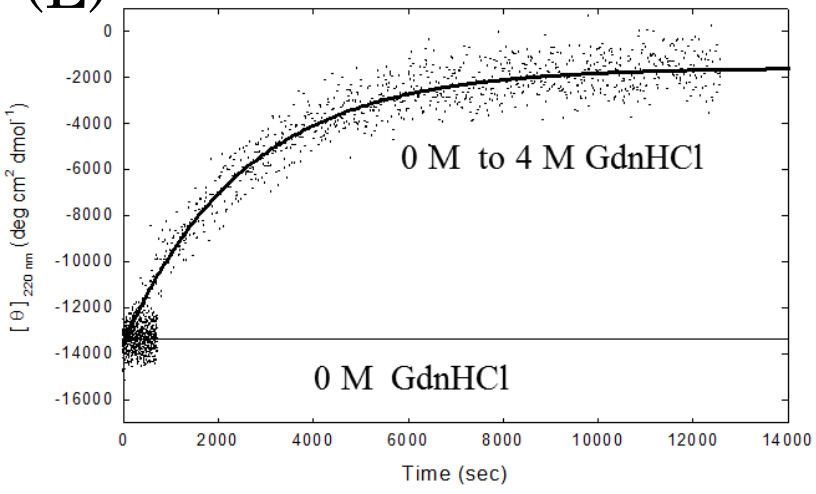

(F)

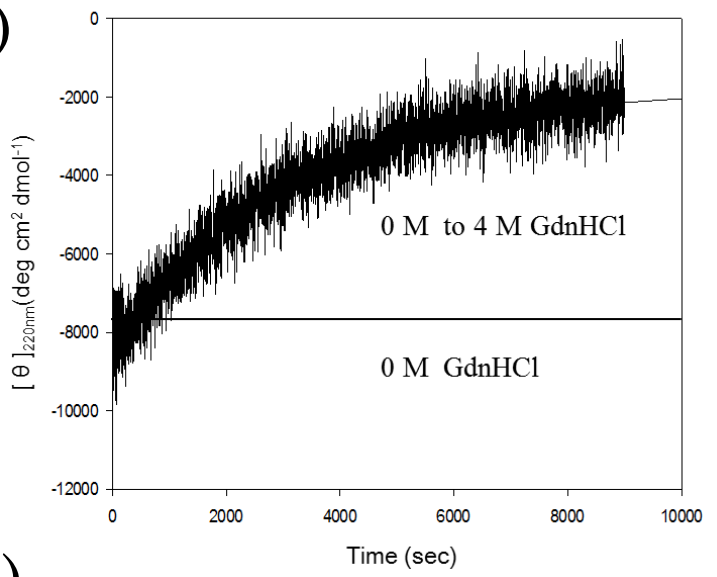

(G)

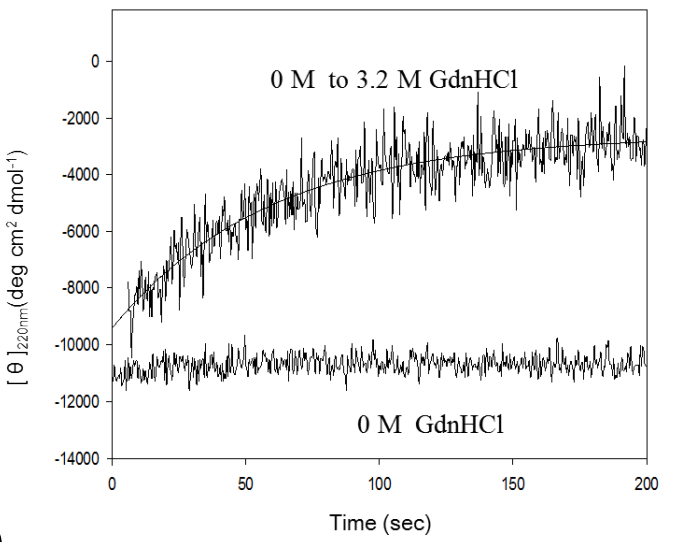

(H)

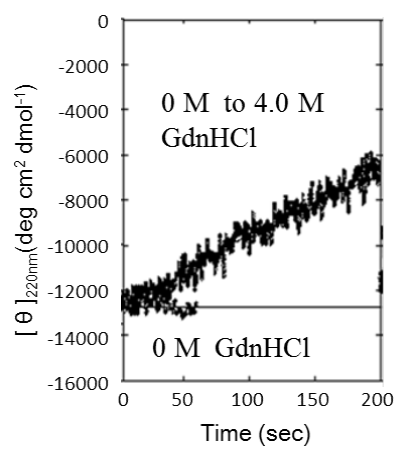

Figure 1: Kinetic unfolding curves of Tk-RNase $\mathrm{H} 2$ and its variants. Unfolding was initiated by rapid dilution of the protein from native to unfolding conditions (0 $\mathrm{M}$ to $3.2 \mathrm{M}$ or $4 \mathrm{M} \mathrm{GdnHCl}$ ), and monitored by $\mathrm{CD}$ at $220 \mathrm{~nm}$. (A) Tk-RNase H2 at $25^{\circ} \mathrm{C}$. (B) D7N at $25^{\circ} \mathrm{C}$. (C) L33A at $25^{\circ} \mathrm{C}$. (D) Tk-RNase H2 at $50^{\circ} \mathrm{C}$. (E) F20 at $25^{\circ} \mathrm{C}$. (F) D7N-F20 at $25^{\circ} \mathrm{C}$. (G) L33A-F20 at $25^{\circ} \mathrm{C}$. (H) F20 at $50^{\circ} \mathrm{C}$. The native state $(0 \mathrm{M} \mathrm{GdnHCl})$ was monitored by $\mathrm{CD}$ at $220 \mathrm{~nm}$. 
(A)

$(\mathrm{kDa}) \quad$ (c) $\quad 0.512248816304560120 \quad(\mathrm{~min})$

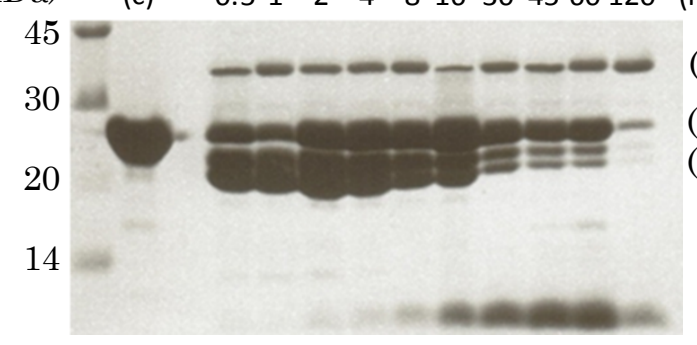

(E) $(\mathrm{F} 22 / 20)$

$(\mathrm{kDa})$

45

(c) $\begin{array}{llllllllll}0.5 & 1 & 2 & 4 & 8 & 16 & 30 & 45 & 60 & (\mathrm{~min})\end{array}$

30

20

14

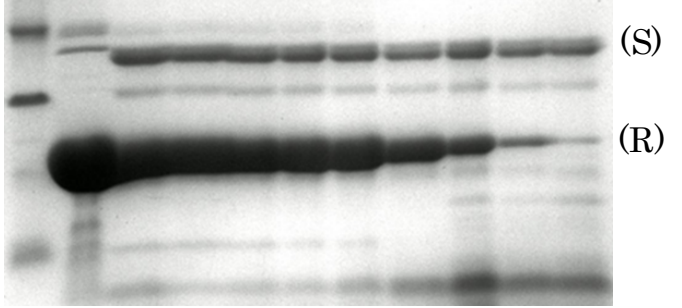

(B)

(kDa) $\quad \begin{array}{lllllllllll}0 & 0.5 & 1 & 2 & 4 & 8 & 16 & 30 & 60 & 120 & \mathrm{o} / \mathrm{n}(\mathrm{min})\end{array}$

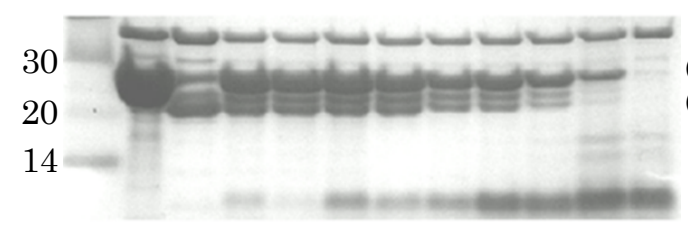

(C)

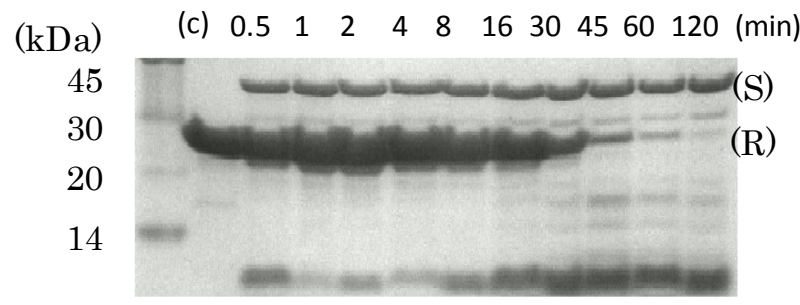

(S)

(R) (F22/20)

(F)

( $\mathrm{kDa})$ $\begin{array}{lllllllllll}0.5 & 1 & 2 & 4 & 8 & 16 & 30 & 45 & 60 & 120 & \text { (min) }\end{array}$

45

30

20

\section{(G)}

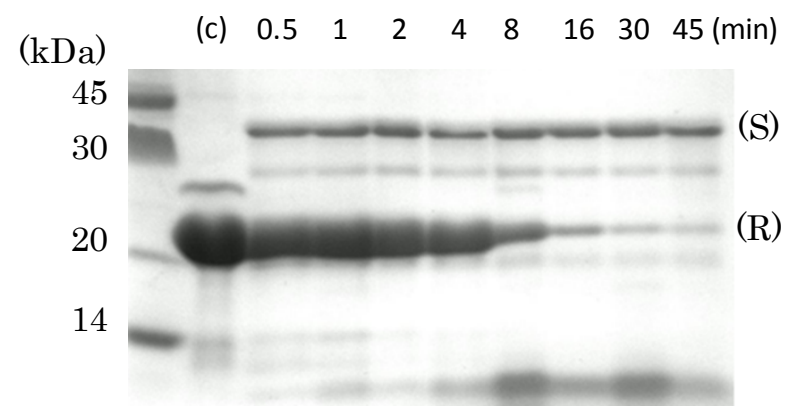

\section{(D)}

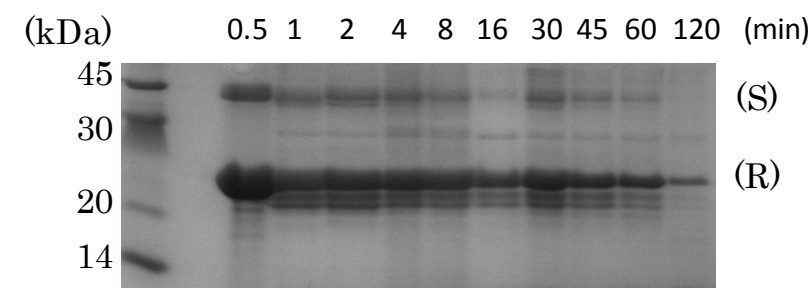

Figure 2: Pulse proteolysis in kinetic unfolding of Tk-RNase $\mathrm{H} 2$ and its variants by Tk-subtilisin. The protein was unfolded by adding $4 \mathrm{M}$ GdnHCl. At each time point $(0.5-120 \mathrm{~min})$, the sample was dispensed into tubes, and proteolysis was performed by the addition of Tk-subtilisin and the sample incubated for $45 \mathrm{~s}$. Proteolysis was quenched by $10 \%$ TCA and the products were quantified by tricine-SDS-PAGE. Lanes (c) contained only Tk-RNase $\mathrm{H} 2$ or each mutant. (A) Tk-RNase $\mathrm{H} 2$ at $25^{\circ} \mathrm{C}$. (B) D7N at $25^{\circ} \mathrm{C}$. (C) L33A at $25^{\circ} \mathrm{C}$. (D) Tk-RNase $\mathrm{H} 2$ at $50^{\circ} \mathrm{C}$. (E) F20 at $25^{\circ} \mathrm{C}$. (F) D7N-F20 at $25^{\circ} \mathrm{C}$. (G) $\mathrm{L} 33 \mathrm{~A}-\mathrm{F} 20$ at $25^{\circ} \mathrm{C}$. Bands corresponding to Tk-subtilisin (S), Tk-RNase $\mathrm{H} 2$ and its variants (R) and cleavage products (F22/20) are indicated 


\begin{tabular}{|c|c|c|}
\hline & $25^{\circ} \mathrm{C}$ & $50^{\circ} \mathrm{C}$ \\
\hline $\begin{array}{c}\text { Tk-RNase H2 } \\
\text { (wild-type) }\end{array}$ & $\begin{array}{c}{[4 \mathrm{M} \mathrm{GdnHCl}]} \\
4.2 \times 10^{-4} \pm 0.5 \times 10^{-4 a}\end{array}$ & $\begin{array}{c}{[4 \mathrm{M} \mathrm{GdnHCl}]} \\
4.2 \times 10^{-3} \pm 0.8 \times 10^{-3 a}\end{array}$ \\
\hline D7N & $\begin{array}{c}{[4 \mathrm{M} \mathrm{GdnHCl}]} \\
2.9 \times 10^{-4} \pm 0.5 \times 10^{-4}\end{array}$ & - \\
\hline L33A & $\begin{array}{c}{[3.2 \mathrm{M} \mathrm{GdnHCl}]} \\
1.3 \times 10^{-2} \pm 0.6 \times 10^{-2}\end{array}$ & - \\
\hline $\mathrm{F} 20$ & $\begin{array}{c}{[4 \mathrm{M} \mathrm{GdnHCl}]^{-4}} \\
6.4 \times 10^{-4} \pm 0.5 \times 10^{-4 a}\end{array}$ & $\begin{array}{c}{[4 \mathrm{M} \mathrm{GdnHCl}]} \\
3.7 \times 10^{-3} \pm 0.8 \times 10^{-3 \mathrm{a}}\end{array}$ \\
\hline D7N-F20 & $\begin{array}{c}{[4 \mathrm{M} \mathrm{GdnHCl}]} \\
3.2 \times 10^{-4} \pm 0.5 \times 10^{-4}\end{array}$ & - \\
\hline L33A-F20 & $\begin{array}{c}{[3.2 \mathrm{M} \mathrm{GdnHCl}]} \\
1.4 \times 10^{-2} \pm 0.6 \times 10^{-2}\end{array}$ & - \\
\hline
\end{tabular}

aData from ref. [14].

Table 2: Unfolding Rate Constants $\left(\mathrm{s}^{-1}\right)$ of Tk-RNase $\mathrm{H} 2$ and Its Variants in $\mathrm{GdnHCl}$ at $\mathrm{pH} 9.0$.
(A)

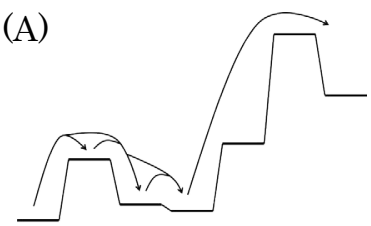

$\begin{array}{llllllll}\mathrm{N} & \mathrm{I}_{A} & \mathrm{I}_{\mathrm{B}} & \mathrm{I}_{\mathrm{C}} & \mathrm{I}_{\mathrm{D}} & \mathrm{TS} & \mathrm{D}\end{array}$

(B)

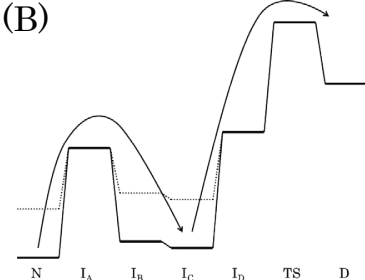

(C)
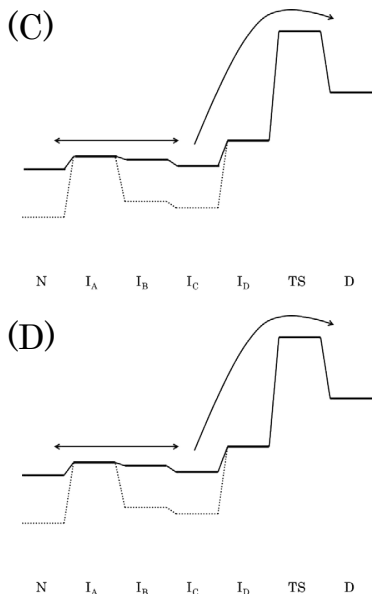

(E)

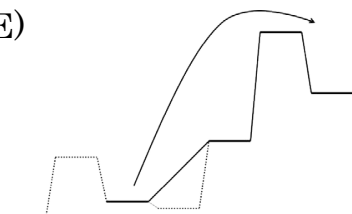

(F)

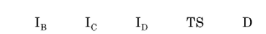

(G)

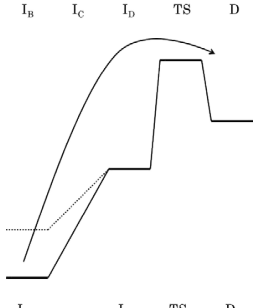

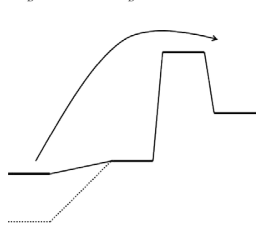

$\mathrm{I}_{\mathrm{B}}-\mathrm{I}_{\mathrm{D}} \quad \mathrm{TS} \quad \mathrm{D}$

Figure 3: Schematic illustrations for the energy diagram of the unfolding process of Tk-RNase $\mathrm{H} 2$ and its variants. (A) Tk-RNase $\mathrm{H} 2$ at $25^{\circ} \mathrm{C}$. (B) D7N at $25^{\circ} \mathrm{C}$. (C) $\mathrm{L} 33 \mathrm{~A}$ at $25^{\circ} \mathrm{C}$. (D) Tk-RNase $\mathrm{H} 2$ at $50^{\circ} \mathrm{C}$. (E) $\mathrm{F} 20$ at $25^{\circ} \mathrm{C}$. (F) $\mathrm{D} 7 \mathrm{~N}-\mathrm{F} 20$ at $25^{\circ} \mathrm{C}$. (G) L33A-F20 at $25^{\circ} \mathrm{C}$. TS, transition state. Arrows indicate the main unfolding routes. Dotted lines in B-E and F-G are the energy diagrams of Tk-RNase $\mathrm{H} 2$ and $\mathrm{F} 20$ at $25^{\circ} \mathrm{C}$, respectively.

and destabilize, respectively, the $\mathrm{N}$-terminal domain, because both mutation sites are located at the $\mathrm{N}$-terminal domain. The $\mathrm{N}$-terminal domain contributes to the stabilization of the $\mathrm{N}-, \mathrm{I}_{\mathrm{B}}$ - and $\mathrm{I}_{\mathrm{C}}$-states [14]. This means that the $\mathrm{N}-, \mathrm{I}_{\mathrm{B}}$ - and $\mathrm{I}_{\mathrm{C}}$-states of $\mathrm{D} 7 \mathrm{~N}$ are more stable than those of Tk-RNase $\mathrm{H} 2$, but the stability of the $\mathrm{I}_{\mathrm{A}}$-state is comparable with that of the wild-type (Figure $3 \mathrm{~B}$ ). Since the $\mathrm{I}_{\mathrm{A}}$-state is less stable

than the $\mathrm{N}-, \mathrm{I}_{\mathrm{B}}$ - and $\mathrm{I}_{\mathrm{C}}$-states of $\mathrm{D} 7 \mathrm{~N}$, the $\mathrm{I}_{\mathrm{A}}$-state was detected only during the burst phase signal in the kinetic unfolding curve of the $\mathrm{CD}$ measurements (Figure 1B), but not by pulse proteolysis (Figure 2B). Furthermore, the change from $I_{B}$-state to $I_{C}$-state in D7N was faster than that in the wild-type (Figure $2 \mathrm{~A}$ and $2 \mathrm{~B}$ ), resulted from the larger difference in stability between the $\mathrm{I}_{\mathrm{A}}$-state and $\mathrm{N}-/ \mathrm{I}_{\mathrm{B}} / \mathrm{I}_{\mathrm{C}}$ states of D7N than that of the wild-type protein (Figure $3 \mathrm{~A}$ and $3 \mathrm{~B}$ ). For L33A, the $\mathrm{N}-, \mathrm{I}_{\mathrm{B}}-$ and $\mathrm{I}_{\mathrm{C}}$-states are destabilized, so that the energy levels of the $\mathrm{N}-, \mathrm{I}_{\mathrm{A}^{-}}, \mathrm{I}_{\mathrm{B}}$ - and $\mathrm{I}_{\mathrm{C}^{-}}$-states are the same degree (Figure $3 \mathrm{C}$ ). In the native environment at $25^{\circ} \mathrm{C}, \mathrm{L} 33 \mathrm{~A}$ fluctuates among these states. Consequently, L33A apparently unfolds from the $\mathrm{I}_{\mathrm{C}}$-state. Likewise, the unfolding of Tk-RNase $\mathrm{H} 2$ at $50^{\circ} \mathrm{C}$ starts from the $\mathrm{I}_{\mathrm{C}}$-state (Figure 3D). Of course, it is difficult to judge the start form, $\mathrm{N}$-state or $\mathrm{I}_{\mathrm{C}}$-state, from the result of pulse proteolysis. The other results, such as pulse proteolysis of the other mutants and kinetic unfolding experiments, however, support this idea. The $\mathrm{I}_{\mathrm{B}}$-states of D7N-F20 and L33A-F20 are stable and unstable, respectively, compared with the stability of this state of F20 (Figure 3E-3G). The unfolding rates of D7N-F20 and L33A-F20 are slower and faster than that of F20, respectively. This information suggests that the $\mathrm{I}_{\mathrm{C}}$-state is the native state of Tk-RNase $\mathrm{H} 2$ at high temperatures in nature.

\section{Conformations of the C-terminal region}

From the $\mathrm{N}$-state to $\mathrm{I}_{\mathrm{C}}$-state, the $\mathrm{C}$-terminal region changes conformation. The structural and mutational analysis of Tk-RNase $\mathrm{H} 2$ showed that the $\mathrm{C}$-terminal region plays an important role in substrate binding and changes conformation during this process [4]. Therefore, the $\mathrm{C}$-terminal region of Tk-RNase $\mathrm{H} 2$ can readily change its conformation. The "native form" of the C-terminal region of Tk-RNase $\mathrm{H} 2$ at high temperatures would shift to a more stable artificial state at lower temperatures. Such non-natural states of thermophilic proteins at lower temperatures have been reported [27-29]. Recombinant catalase I from Bacillus stearothermophilus and glutamate dehydrogenases from Pyrobaculum islandicum and T. kodakarensis expressed at moderate temperatures convert into active forms following heat treatment. For Tk-RNase $\mathrm{H} 2$, the $\mathrm{N}$-state is the most stable form at lower temperatures and the $\mathrm{I}_{\mathrm{C}}$-state is the active form at higher temperatures, where the host organism, T. kodakarensis, can grow.

\section{Conclusion}

Tk-RNase H2 unfolds through the multiple intermediate states at moderate temperatures. Our pulse proteolysis analysis of the wildtype and mutant proteins at different temperatures reveals that the unfolding pathway at higher temperatures is more simply than that at lower temperatures. We could observe the artificial forms at lower temperatures and the real native state at higher temperatures.

\section{Acknowledgments}

This work was supported in part by Grants (22710215 and 25440194) from the Ministry of Education, Culture, Sports, Science and Technology of Japan.

\section{References}

1. Haruki M, Hayashi K, Kochi T, Muroya A, Koga Y, et al. (1998) Gene cloning and characterization of recombinant RNase HII from a hyperthermophilic archaeon. J Bacteriol 180: 6207-6214.

2. Crouch RJ, Dirksen ML (1982) Ribonuclease H: In Nuclease. Linn SM, Roberts RJ, Cold Spring Harbor Laboratory: Cold Spring Harbor, NY.

3. Ohtani N, Haruki M, Morikawa M, Kanaya S (1999) Molecular diversities of RNases H. J Biosci Bioeng 88: 12-19.

4. Muroya A, Tsuchiya D, Ishikawa M, Haruki M, Morikawa M, et al. (2001) Catalytic center of an archaeal type ribonuclease $\mathrm{H}$ as revealed by $\mathrm{X}$-ray crystallographic and mutational analyses. Protein Sci 10: 707-714. 
Citation: Shima K, Nagao A, Okada J, Sano S, Takano K (2015) Slow Unfolding Pathway of the Hyperthermophilic Tk-RNase H2 Examined by Pulse Proteolysis Using Mutant Proteins. Biochem Anal Biochem 4: 213. doi:10.4172/2161-1009.1000213

5. Takano K, Endo S, Mukaiyama A, Chon $\mathrm{H}$, Matsumura $\mathrm{H}$, et al. (2006) Structure of amyloid beta fragments in aqueous environments. FEBS $\mathrm{J} 273$ : 150-158.

6. Takano K, Katagiri Y, Mukaiyama A, Chon H, Matsumura H, et al. (2007) Conformational contagion in a protein: structural properties of a chameleon sequence. Proteins 68: 617-625.

7. Mukaiyama A, Takano K, Haruki M, Morikawa M, Kanaya S (2004) Kinetically robust monomeric protein from a hyperthermophile. Biochemistry 43: 1385913866

8. Mukaiyama A, Haruki M, Ota M, Koga Y, Takano K, et al. (2006) A hyperthermophilic protein acquires function at the cost of stability. Biochemistry 45: 12673-12679.

9. Dong H, Mukaiyama A, Tadokoro T, Koga Y, Takano K, et al. (2008) Hydrophobic effect on the stability and folding of a hyperthermophilic protein. $J$ Mol Biol 378: 264-272

10. Mukaiyama A, Koga Y, Takano K, Kanaya S (2008) Osmolyte effect on the stability and folding of a hyperthermophilic protein. Proteins 71: 110-118.

11. Takano K, Higashi R, Okada J, Mukaiyama A, Tadokoro T, et al. (2009) Proline effect on the thermostability and slow unfolding of a hyperthermophilic protein. J Biochem 145: 79-85

12. Mukaiyama A, Takano K (2009) Slow unfolding of monomeric proteins from hyperthermophiles with reversible unfolding. Int J Mol Sci 10: 1369-1385.

13. Okada J, Okamoto T, Mukaiyama A, Tadokoro T, You DJ, et al. (2010) Evolution and thermodynamics of the slow unfolding of hyperstable monomeric proteins. BMC Evol Biol 10: 207.

14. Okada J, Koga Y, Takano K, Kanaya S (2012) Slow unfolding pathway of hyperthermophilic Tk-RNase Hexamined by pulse proteolysis using the stable protease Tk-subtilisin. Biochemistry 51: 9178-9191.

15. Pulido M, Saito K, Tanaka S, Koga Y, Morikawa M, et al. (2006) Ca2+-dependent maturation of subtilisin from a hyperthermophilic archaeon, Thermococcus kodakaraensis: the propeptide is a potent inhibitor of the mature domain but is not required for its folding. Appl Environ Microbiol 72: 4154-4162.

16. Tanaka S, Saito K, Chon H, Matsumura H, Koga Y, et al. (2007) Crystal structure of unautoprocessed precursor of subtilisin from a hyperthermophilic archaeon. J Biol Chem 282: 8246-8255.

17. Tanaka S, Matsumura H, Koga Y, Takano K, Kanaya S (2007) Four new crystal structures of Tk-subtilisin in unautoprocessed, autoprocessed and mature forms: Insight into structural changes during maturation. J Mol Biol 372: 10551069
18. Pulido MA, Koga Y, Takano K, Kanaya S (2007) Directed evolution of Tksubtilisin from a hyperthermophilic archaeon: identification of a single amino acid substitution responsible for low-temperature adaptation. Protein Eng Des Sel 20: 143-153.

19. Pulido MA, Tanaka S, Sringiew C, You DJ, Matsumura H, et al. (2007) Requirement of left-handed glycine residue for high stability of the Tk-subtilisin propeptide as revealed by mutational and crystallographic analyses. J Mol Bio 374: $1359-1373$

20. Tanaka S, Takeuchi Y, Matsumura H, Koga Y, Takano K, et al. (2008) Crysta structure of Tk-subtilisin folded without propeptide: requirement of propeptide for acceleration of folding. FEBS Lett 582: 3875-3878.

21. Tanaka S, Matsumura H, Koga Y, Takano K, Kanaya S (2009) Identification of the interactions critical for propeptide-catalyzed folding of Tk-Subtilisin. J Mol Biol 394: 306-319

22. Takeuchi Y, Tanaka S, Matsumura H, Koga Y, Takano K, et al. (2009) Requirement of a unique $\mathrm{Ca}(2+)$-binding loop for folding of Tk-subtilisin from a hyperthermophilic archaeon. Biochemistry 48: 10637-10643.

23. Uehara R, Takeuchi Y, Tanaka S, Takano K, Koga Y, et al. (2012) Requirement of $\mathrm{Ca}(2+)$ ions for the hyperthermostability of Tk-subtilisin from Thermococcus kodakarensis. Biochemistry 51: 5369-5378.

24. Koga Y, Tanaka S, Sakudo A, Tobiume M, Aranishi M, et al. (2014) Proteolysis of abnormal prion protein with a thermostable protease from Thermococcus kodakarensis KOD1. Appl Microbiol Biotechnol 98: 2113-2120.

25. Hirata A, Sakudo A, Takano K, Kanaya S, Koga Y (2015) Effects of surfactant and a hyperthermostable protease on infectivity of scrapie-infected mouse brain homogenate. J Biotechnol Biomater 5: 194.

26. Schneider CA, Rasband WS, Eliceiri KW (2012) NIH Image to Image J: 25 years of image analysis. Nat Methods 9: 671-675.

27. Kobayashi C, Suga Y, Yamamoto K, Yomo T, Ogasahara K, et al. (1997) Thermal conversion from low- to high-activity forms of catalase I from Bacillus stearothermophilus. J Biol Chem 272: 23011-23016.

28. Goda S, Kojima M, Nishikawa Y, Kujo C, Kawakami R, et al. (2005) Intersubunit interaction induced by subunit rearrangement is essential for the catalytic activity of the hyperthermophilic glutamate dehydrogenase from Pyrobaculum islandicum. Biochemistry 44: 15304-15313.

29. Izumikawa N, Shiraki K, Nishikori S, Fujiwara S, Imanaka T, et al. (2004 Biophysical analysis of heat-induced structural maturation of glutamate dehydrogenase from a hyperthermophilic archaeon. J Biosci Bioeng 97: 305-309. 